\title{
Annual Report on the External Quality Assessment Scheme for Blood Bank Tests in Korea (2015)
}

Young Ae Lim ${ }^{1}$, Hyun Soo $\mathrm{Cho}^{1}$, Seog Woon Kwon ${ }^{2}$, Kye Chul Kwon ${ }^{3}$, Shin Young Kim ${ }^{4}$, Kyung Un Park ${ }^{5}$, Hyun Jun Park ${ }^{2}$, Woon Heung Song ${ }^{6}$, Duck $\mathrm{Cho}^{7}$, Tae Hyoun $\mathrm{Um}^{8}$, Mee Kyung Lee ${ }^{9}$, and Sang Moo $\mathrm{Han}^{10}$, as the Blood Bank Subcommittee, Korean Association of External Quality Assessment Service

${ }^{1}$ Department of Laboratory Medicine, Ajou University School of Medicine, Suwon; ${ }^{2}$ Department of Laboratory Medicine, Asan Medical Center, Ulsan University School of Medicine, Seoul; ${ }^{3}$ Department of Laboratory Medicine, Chungnam University Hospital, Daejeon; ${ }^{4}$ Department of Laboratory Medicine, Severance Hospital, Yonsei University College of Medicine, Seoul; ${ }^{5}$ Department of Laboratory Medicine, Seoul National University Bundang Hospital, Seongnam; ${ }^{6}$ Department of Biomedical Laboratory Science, Shinhan University, Uijeongbu; ${ }^{7}$ Department of Laboratory Medicine, Chonnam National University Hwasun Hospital, Hwasun; ${ }^{8}$ Department of Laboratory Medicine, Inje University Ilsan Paik Hospital, Goyang; ${ }^{\circ}$ Blood Laboratory Center Central, Korean Red Cross, Seoul; ${ }^{10}$ Gyeonggi Red Cross Blood Center, Korean Red Cross, Suwon, Korea

Corresponding author: Young Ae Lim

Department of Laboratory Medicine, Ajou University Hospital, Ajou University School of Medicine, 164 World Cup-ro, Yeongtong-gu, Suwon 16499, Korea

Tel: +82-31-219-5786

Fax: +82-31-219-5778

E-mail: limyoung@ajou.ac.kr

pISSN: 2384-2458

eISSN: $2288-7261$
We report here the results of the external quality assessment scheme (EQA) of blood bank tests in Korea carried out in 2015. The proficiency testing specimens used in the survey were prepared at Ajou University Hospital. The response rates from participating laboratories for the first and second trials were $98.7 \%$ (542/549) and 98.2\% (544/554), respectively. No answers to tests were considered incorrect, and the average accuracy rates for six different test items on the standard survey were as follows: $\mathrm{ABO}$ grouping, $99.4 \%$ to $100.0 \%$; $\mathrm{RhD}$ typing, $99.4 \%$ to $100.0 \%$; crossmatching, $93.6 \%$ to $99.0 \%$; direct antiglobulin test (DAT) using a polyspecific reagent, $92.9 \%$ to $98.3 \%$; DAT using an IgG monospecific reagent, $94.6 \%$ to $100.0 \%$; DAT using a C3d monospecific reagent, $84.2 \%$ to $98.6 \%$; unexpected antibody screening test, $94.5 \%$ to $100.0 \%$; and antibody identification test, $93.8 \%$ to $100.0 \%$. We performed a pilot survey on reactivities to $\mathrm{A}_{1}$ (54 responses) and $\mathrm{H}$ (50 responses); Rh C, c, $\mathrm{E}$, and e antigen testing (47 responses); and $\mathrm{ABO}$ antibody titration (10-34 responses). We obtained excellent results for this EQA, and these results will be helpful for improving or maintaining the quality of the participating laboratories.

(J Lab Med Qual Assur 2016;38:59-67)

Key Words: Blood bank, Laboratory proficiency testing 


\section{Journal of LABORATORY MEDICINE and QUALITY ASSURANCE}

\section{Young Ae Lim et al • Annual Report on EQA in Blood Banks}

\section{서론}

혈액은행검사는 수혈 전에 시행하는 $\mathrm{ABO}$ 및 $\mathrm{RhD}$ 혈액형 검사, 비예기항체 선별 및 동정검사, 교차시험이 포함되어 있 다. 이들 검사의 정확성은 환자의 생명과도 직결되는 매우 중 요한 요소이다. 대부분 혈액은행에서 실시하고 있는 검사의 원 리는 적혈구와 혈장 혹은 혈청을 이용한 면역혈구 응집법 검 사이다. 그러나 이러한 검사들의 내부정도관리물질들은 널리 상품화되어 있지도 않을뿐더러 상품화되어 있는 물질은 고가 이기 때문에 일반 검사실에서는 이들을 구입하여 사용하기보 다는 대부분 자가제조물질을 사용하고 있는 실정이다. 이러한 이유로 혈액은행검사의 외부정도관리 참여는 혈액은행검사의 신뢰도를 평가할 수 있는 매우 중요한 과정이라고 할 수 있다.

2015년 혈액은행분과 신빙도조사에는 2014년까지 참여했 던 기관과 [1] 신규가입 기관을 포함하여 모두 554기관이 참여 하였다. 이 기관들의 종사자들을 대상으로 교육을 강조하기 위 하여 혈액은행 업무에 필요한 실기와 강의 워크숍을 1 회 개최 하였다.

이에 저자들은 2015 년에 혈액은행분과에서 실시한 $\mathrm{ABO}$ 혈 액형검사, $\mathrm{RhD}$ 혈액형검사, 교차시험검사, 직접항글로불린검 사, 비예기항체 선별검사 및 항체동정검사 등 총 6 가지 항목과 추가로 실시한 두 가지 종류의 시범항목에 대한 외부 신빙도조 사를 정리하였고, 기관별 검사방법에 대한 결과와 실시하였던 워크숍 개최에 대한 사업내용을 보고하고자 한다.

\section{재료 및 방법}

\section{1. 참여기관}

2015년도 혈액은행 외부 신빙도조사 대상기관은 2014년까 지 신빙도조사에 참여하였던 기관과 신규 가입기관을 대상으 로 하였다. 2015년 5월과 11월 총 2차에 걸쳐 외부 신빙도조사 를 실시하였으며, 1 회차에 549 기관, 2 회차에 554 기관에 검체 를 발송하였다.

\section{2. 조사항목 및 검체 제조}

조사항목은 예년과 마찬가지로 $\mathrm{ABO}$ 혈액형검사, $\mathrm{RhD}$ 혈액 형검사, 교차시험검사, 직접항글로불린검사, 비예기항체 선별 검사 및 동정검사 등 6 가지 항목에 대한 외부 신빙도조사를 실 시하였다 [1-5]. 시범항목으로 1 회차 때는 적혈구 $\mathrm{A}_{1}$ 과 $\mathrm{H}$ 항 원, 2 회차 때는 $\mathrm{ABO}$ 항체 역가검사를 시범항목으로 추가하였 다.

\section{1) $\mathrm{ABO}$ 혈액형검사}

$\mathrm{ABO}$ 혈액형검사는 $\mathrm{A}$ 형, $\mathrm{B}$ 형, $\mathrm{O}$ 형, $\mathrm{AB}$ 형 중 무작위로 검 체를 선별하여 혈구형검사와 혈청형검사가 가능하도록 매회 3 개의 $\mathrm{ABO}$ 혈구용과 3 개의 $\mathrm{ABO}$ 혈청용 검체를 제조하였다. 모든 정도관리 검체는 기존의 방법처럼 [1-5] 아주대병원 혈 액은행에서 제조하였는데 혈구 검체는 대한적십자사에서 공 급받은 CPDA (citrate phosphate dextrose adenine)-1 혈 액 백에서 분리된 농축적혈구를 혈구보존액인 EC Stabilizing solution (DiaMed GmbH, Cressier, Switerland)을 사용하 여 $3 \%$ 로 희석하였으며, 혈청용 검체는 신선동결혈장을 냉동 보관한 후 무균봉합기로 연결하여 혼합한 다음 분주하였다.

\section{2) $\mathrm{RhD}$ 혈액형검사}

$\mathrm{RhD}$ 혈액형검사는 $\mathrm{ABO}$ 혈액형검사에 사용된 혈구를 이용 하여 검사하도록 하였다.

\section{3) 교차시험검사}

교차시험검사는 매회 3 종류의 검체를 이용하여 교차시험을 실시하게 하였는데 검체별로 실온식염수법, $37^{\circ} \mathrm{C}$ 알부민법, 항글로불린법 단계의 반응을 달리하여 3 단계를 모두 점검할 수 있도록 검체를 제조하여 발송하였다. 검체는 상품화된 인간 유래 다클론성 anti-D (DiaMed $\mathrm{GmbH}$ )를 폐기 혈장에 첨가 하여 반응 역가를 결정한 후 사용하였다.

\section{4) 직접항글로불린검사}

직접항글로불린검사는 1,2 차 모두 음성 결과와 양성 결 과를 나타내는 두 가지 유형의 검체를 발송하였다. 직접항글 로불린검사용 검체는 인간유래 다클론성 anti-D (DiaMed $\mathrm{GmbH}$ )를 사용하여 인위적으로 감작시킨 혈구를 사용하였다.

\section{5) 비예기항체 선별검사 및 동정검사}

비예기항체 선별검사 및 동정검사는 항체선별검사만 실시하 는 기관과 동정검사까지 실시하는 기관을 분류하여 검체가 발 송되었다. 즉 비예기항체 선별검사만 실시하는 기관에는 2 종 류의 검체가 2 차에 걸쳐 운송되었으며, 비예기항체 동정검사 까지 실시한 기관은 3 종류의 검체가 2 차에 걸쳐 운송되어 총 4 검체에서 6 검체까지 검사를 실시하였다. 항체선별검사만을 실 시하는 기관에는 1 회차는 모두 양성인 검체, 2 회차는 양성과 음성 검체를 발송하였으며, 동정검사를 실시하는 기관에는 1 회차 양성인 검체 3 개, 2 회차 음성인 검체 1 개와 양성인 검체 2 개를 발송하였다.

비예기항체 동정용 양성 검체로는 1 회차 anti- $\mathrm{D}$, anti-c, 
anti-M, 2회차 anti-D, anti-e를 발송하였는데 anti-M은 한 마음혈액원에서 비예기항체 양성인 신선동결 혈장을 공급받 아 사용하였다. 다른 검체는 항혈청 시약을 각각 희석하여 사 용하였는데, 상품화된 인간유래 다클론성 anti-D (DiaMed $\mathrm{GmbH}$ ), 단클론성 anti-e, anti-c (Diagast, Parc Eurasanté, France)를 폐기혈청에 첨가한 후 항글로불린 단계에서의 혈 구 응집 정도를 조절하여 제조하였다.

\section{6) 시범항목}

1 회차 때는 적혈구 $\mathrm{A}_{1}, \mathrm{H}$ 항원검사 및 $\mathrm{Rh}$ subgrouping 검 사항목인 C, c, E, e 항원검사를 시행하였는데, 검체는 $\mathrm{ABO}$ 와 $\mathrm{RhD}$ 혈액형 검사에 사용된 혈구를 이용하여 검사하도록 하였다. 2회차 때는 $\mathrm{ABO} \mathrm{Ab}$ 역가검사를 실시하였는데, 검체 는 $\mathrm{AB}$ 형 신선동결혈장을 이용하였다.

\section{7) 워크숍 개최}

혈액은행 실기 워크숍은 혈액은행분과 단독으로 주관하여 총 2 회의 워크숍을 개최하고자 하였으나 메르스 감염과 관련 하여 1,2 차를 통합하여 1 회를 개최하였고, 워크솝에 대한 공 지는 개최 전에 홈페이지의 게시판과 문자수신 등을 이용하였 다.

\section{3. 검체 우송 및 정답 확인}

자가제조된 모든 검체는 검사자 2 인이 각각 검사하여 결과 및 응집 정도를 확인하였다. 검체의 파손을 줄이기 위하여 에 어 비닐을 이용하여 검체를 포장하였고, 참여기관에 도착 전까 지의 검체의 실온 노출기간을 최소화하기 위하여 제조 및 포장 된 검체를 냉장 보관하였다가 월요일에 일괄 익일배송하였다. 정답률 산정 시는 검사법이 다양하여 참여기관의 수를 정확히 산정하기 곤란한 교차시험을 제외하고는 미입력 기관은 오답 으로 처리하였다.

\section{결과}

\section{1. 신빙도조사 참여기관 수 및 회신율}

2015년 혈액은행분과 신빙도조사의 참여기관 및 회신율 은 Table 1에 기술하였는데, 6 가지의 신빙도조사항목 중 한 종목의 한 가지 검체라도 결과를 보낸 기관은 모두 포함시켰 다. 검체가 발송된 기관 수는 1회차(2회차)가 549 (554)기관 으로 평균 552 기관이었으며, 회신기관 수는 1 회차(2회차)가 542 (544)기관으로 평균 543 기관으로 회신율 1회차(2회차)가 $98.7 \%(98.2 \%)$ 로 평균 $98.4 \%$ 였다.
조사항목별로 평균 회신기관 수를 살펴보면 $\mathrm{ABO}$ 혈액형검 사를 시행하는 543 기관을 $100 \%$ 로 간주할 경우 $\mathrm{RhD}$ 검사는 537 기관(98.8\%), 교차시험은 479 기관(88.2\%), 직접항글로불 린검사는 375 기관 $(69.1 \%)$, 항체선별검사는 299 기관(55.1\%), 그리고 항체동정검사는 132 기관에서(24.3\%) 결과를 회신하 였다(Table 1). 항체선별검사에 참여한 기관이 작년에 비하여 14 기관 증가한 것을 제외하고는 각 종목별 회신율은 예년과 유사하였다.

\section{2. 조사항목}

\section{1) $\mathrm{ABO}$ 혈액형검사}

$\mathrm{ABO}$ 혈액형검사는 2 차에 걸쳐 총 6 개의 검체로 실시하였 고, 1 차는 $99.4 \%-99.6 \%, 2$ 차는 $99.4 \%-100.0 \%$ 의 정답률을 나타내는데, 한 개의 검체라도 미입력을 보여 오답으로 간주된 기관은 1 회차에 1 기관, 2 회차에 1 기관이었다(Table 2). 1차(2 차)의 혈구형검사법은 시험관법이 $49.3 \%$ (50.0\%)로 가장 많 이 사용하는 방법으로 나타났으며, 그 뒤를 이어 슬라이드법 이 $40.2 \%$ (42.1\%)이었으며, 마이크로웰 플레이트법이 9.2\% (7.2\%)을 차지하였다. 1 차(2차)의 혈청형검사법은 시험관법 이 $83.6 \%(85.7 \%)$ 로 가장 많이 사용하는 방법으로 나타났으 며, 그 뒤를 이어 슬라이드법이 $7.9 \%$ (8.1\%)이었으며, 마이 크로웰 플레이트법은 2.6\% (1.6\%)를 차지하였다(Table 3). $\mathrm{ABO}$ 혈액형검사의 혈청형검사를 위해서 사용하는 적혈구는 1 차와 2 차는 회신기관의 $62.5 \%$ 와 $61.6 \%$ 에서 자가제조법으 로 제조하여 사용하였다고 보고하였다.

\section{2) $\mathrm{RhD}$ 혈액형검사}

$\mathrm{RhD}$ 혈액형검사결과 1차는 $99.4 \%-100.0 \%, 2$ 차는 $99.4 \%-$ $100.0 \%$ 의 정답률을 나타내었다(Table 2). 1차(2차)의 검사법 은 1 차에서는 시험관법이 $52.5 \%$ 를 차지하여 가장 많이 사용

Table 1. Average number (percentage) of responses for each test in the first and second trials of the survey

\begin{tabular}{llll}
\hline \multicolumn{1}{c}{ Survey item } & \multicolumn{1}{c}{ 2015-1* } & \multicolumn{1}{c}{ 2015-2 } & \multicolumn{1}{c}{ Mean } \\
\hline ABO grouping & $542(100.0)$ & $544(100.0)$ & $543(100.0)$ \\
RhD typing & $539(99.4)$ & $535(98.3)$ & $537(98.8)$ \\
Crossmatching & $481(88.7)$ & $478(87.9)$ & $479(88.2)$ \\
Direct antiglobulin test & $374(69.0)$ & $377(69.3)$ & $375(69.1)$ \\
Ab screening test & $299(55.2)$ & $300(55.1)$ & $299(55.1)$ \\
Ab identification test & $132(24.4)$ & $132(24.3)$ & $132(24.3)$ \\
\hline
\end{tabular}

Abbreviation: $\mathrm{Ab}$, antibody.

${ }^{*}$ Results of the first trial. ${ }^{\dagger}$ Results of the second trial. 
Journal of LABORATORY MEDICINE and QUALITY ASSURANCE

Young Ae Lim et al • Annual Report on EQA in Blood Banks

Table 2. Results of $\mathrm{ABO}$ grouping and $\mathrm{RhD}$ typing

\begin{tabular}{|c|c|c|c|c|c|c|}
\hline Survey no. & Specimen & Participants & Correct answer (\%) & Specimen & Participants & Correct answer (\%) \\
\hline \multirow[t]{3}{*}{ 2015-1 } & Group A & $542\left(2^{\star}\right)$ & $540(99.6)$ & $\mathrm{RhD}(\mathrm{P})$ & 539 & $538(99.8)$ \\
\hline & Group O & $542\left(1^{\star}\right)$ & $539(99.4)$ & $\mathrm{RhD}(\mathrm{P})$ & 539 & $539(100.0)$ \\
\hline & Group $A B$ & $542\left(1^{\star}\right)$ & 540 (99.6) & $\mathrm{RhD}(\mathrm{N})$ & 539 & $536(99.4)$ \\
\hline \multirow[t]{3}{*}{$2015-2$} & Group O & 544 & $543(99.8)$ & $\mathrm{RhD}(\mathrm{P})$ & 535 & $535(100.0)$ \\
\hline & Group B & 544 & $544(100.0)$ & $\mathrm{RhD}(\mathrm{P})$ & 535 & $535(100.0)$ \\
\hline & Group A & $544\left(1^{\star}\right)$ & $541(99.4)$ & $\operatorname{RhD}(\mathrm{N})$ & 535 & $532(99.4)$ \\
\hline
\end{tabular}

Abbreviations: $\mathrm{P}$, positive; $\mathrm{N}$, negative.

${ }^{*} \mathrm{~N}$ of non-responders.

Table 3. Percentage of participating laboratories reporting results of $\mathrm{ABO}$ and $\mathrm{RhD}$ typing according to technique

\begin{tabular}{|c|c|c|c|c|c|c|}
\hline \multirow{3}{*}{ Technique } & \multicolumn{4}{|c|}{ ABO typing } & \multicolumn{2}{|c|}{ RhD typing } \\
\hline & \multicolumn{2}{|c|}{ 2015-1 } & \multicolumn{2}{|c|}{ 2015-2 } & \multirow{2}{*}{ 2015-1 (\%) } & \multirow{2}{*}{$2015-2(\%)$} \\
\hline & Cell (\%) & Serum $(\%)$ & Cell (\%) & Serum $(\%)$ & & \\
\hline Slide & $218(40.2)$ & $43(7.9)$ & $229(42.1)$ & $44(8.1)$ & $199(36.9)$ & $206(38.5)$ \\
\hline Tube & $267(49.3)$ & $453(83.6)$ & $272(50.2)$ & $466(85.7)$ & $280(52.0)$ & $278(52.0)$ \\
\hline Microwell & $50(9.2)$ & $14(2.6)$ & $39(7.2)$ & $9(1.6)$ & 47 (8.7) & $39(7.3)$ \\
\hline Column agglutination technology & $4(0.7)$ & $5(0.9)$ & $4(0.7)$ & $4(0.7)$ & $6(1.1)$ & $9(1.7)$ \\
\hline Solid phase red cell adherence technique & $1(0.2)$ & $1(0.2)$ & 0 & 0 & $1(0.2)$ & 0 \\
\hline No results & $2(0.4)$ & $26(4.8)$ & 0 & $21(3.9)$ & $6(1.1)$ & $3(0.5)$ \\
\hline Total & 542 & 537 & 544 & 544 & 539 & 535 \\
\hline
\end{tabular}

Table 4. Performance in crossmatching

\begin{tabular}{|c|c|c|c|c|c|c|}
\hline \multirow{2}{*}{ Survey no. } & \multirow{2}{*}{ Specimen (S, A, AHG) } & \multirow{2}{*}{ Participants } & \multirow{2}{*}{ Correct decision } & \multicolumn{3}{|c|}{ Participant consensus (\%) } \\
\hline & & & & Saline & Albumin $37^{\circ} \mathrm{C}$ & AHG \\
\hline \multirow[t]{3}{*}{$2015-1$} & Compatible $(-,-,-)$ & 481 & $476(99.0)$ & $370(99.2)$ & $369(99.5)$ & 463 (98.9) \\
\hline & Incompatible $(-,+,+)$ & 481 & $473(98.3)$ & $327(87.2)$ & $366(98.1)$ & $456(98.5)$ \\
\hline & Incompatible $(-,+,+)$ & 481 & $450(93.6)$ & $363(96.8)$ & $366(98.1)$ & $442(93.8)$ \\
\hline \multirow[t]{3}{*}{$2015-2$} & Compatible $(-,-,-)$ & 478 & $468(97.9)$ & $362(98.1)$ & $357(98.1)$ & $456(97.6)$ \\
\hline & Incompatible $(-,+,+)$ & 478 & $452(94.6)$ & $342(92.7)$ & $361(98.9)$ & $445(95.1)$ \\
\hline & Compatible $(-,-,-)$ & 478 & $460(96.2)$ & $360(97.6)$ & $355(97.5)$ & $452(96.8)$ \\
\hline
\end{tabular}

Abbreviations: $\mathrm{S}$, saline or low ionic strength saline at room temperature; $\mathrm{A}, 37^{\circ} \mathrm{C}$ incubations with or without the addition of albumin; $\mathrm{AHG}$, anti-human globulin; +, positive; -, negative.

하는 방법으로 나타났으며, 슬라이드법이 $37.3 \%$, 마이크로웰 플레이트법이 $8.8 \%$ 로 나타났다. 2 차 결과에서도 시험관법이 $52.3 \%$ 로 슬라이드법 $38.7 \%$ 보다 높은 것으로 나타났다. 그 뒤 마이크로웰 플레이트법이 $7.3 \%$ 를 차지하였다(Table 3).

\section{3) 교차시험검사}

교차시험검사는 2 차에 걸쳐 총 6 개의 검체가 사용되었으며, 1 차는 93.6\%-99.0\%, 2차는 94.6\%-97.9\%에서 정답률을 보
였다. 적합 및 부적합 검체에 대하여 각 단계별 정답률을 분 석한 결과, 적합 검체가 $97.6 \%-99.2 \%$ 이고, 부적합 검체가 87.2\%-98.9\%로 부적합 검체에서 오답률이 더 높았으며, 오답 은 부적합 검체의 실온식염수 단계와 알부민 단계에서 응집을 강하게 판독한 기관들에서 나타났다(Table 4). 검사법은 시험 관법이 1 차(2차)가 각각 $79.2 \%$ (78.0\%)로 가장 많이 사용하 는 방법으로 나타났으며, 미세원주응집법 $20.8 \%$ (22.0\%)을 차지하였다. 


\section{Journal of LABORATORY MEDICINE and QUALITY ASSURANCE}

\section{Young Ae Lim et al • Annual Report on EQA in Blood Banks}

\section{4) 직접항글로불린검사}

직접항글로불린검사는 2 차에 걸쳐 총 4 개의 검체가 사용되 었는데, 다특이성 항글로불린법의 1차(2차)의 정답률은 양성 검체 $92.9 \%$ (97.6\%), 음성 검체 $98.3 \%$ (96.5\%)로 양성 검체 에 대한 오답률이 더 높은 것으로 분석되어 예년과 동일한 양 상을 보였다. 1차(2차)의 IgG 단특이성 항글로불린을 사용한 경우 음성이었던 검체에 대한 정답률은 $97.2 \%$ (100.0\%)로 양 성이었던 검체에 대한 정답률 $94.6 \%$ (100.0\%)에 비하여 높 았다. 또한 C3d 단특이성 항글로불린을 사용한 경우는 음성이 었던 검체에 대한 정답률은 $97.3 \%$ (98.6\%)로 양성이었던 검 체에 대한 정답률 93.2\% (84.2\%)에 비하여 높았다(Table 5). 검사법은 미세원주응집법이 1차(2차)가 각각 $50.4 \%$ (52.1\%) 씩으로 가장 많이 사용하였으며 시험관법이 $49.6 \%$ (47.9\%) 로 나타났다.

\section{5) 비예기항체 선별 및 동정검사}

항체선별검사의 정답은 1 회차는 모두 양성, 2 회차는 양성과 음성이었으며, 1 회차는 94.5\%-99.7\%의 정답률을 나타내었 고, 2 회차는 양성은 $99.3 \%-99.7 \%$ 음성인 검체는 $100.0 \%$ 의 정답률을 나타났다. 항체 동정검사의 정답률은 anti- $\mathrm{D}$ 는 1 차 $100.0 \%$ (2차 100.0\%), anti-c는 99.2\%, anti-M은 93.8\%, 2 차 anti-e는 $97.7 \%$ 정답률을 보였다(Table 6). 미입력 기관은
anti-M 1기관, anti-e 3기관으로 모두 오답으로 처리하였다.

1 차(2차)의 항체선별검사법은 미세원주응집법이 $90.9 \%$ $(92.0 \%)$ 로 가장 많이 사용하는 방법이며, 항체동정검사법 도 항체선별검사법과 유사한 양상을 보였는데, 미세원주응집 법 97.8\% (96.3\%)로 가장 많이 사용하는 방법으로 나타났 다. 반면 마이크로웰 플레이트법으로 시행하는 기관은 없었 으며, 2015년부터 새로 코드를 신설한 고형상적혈구부착법 (solid phase red cell adherence assay)이나 적혈구자기화법 (erythrocyte-magnetized technique)으로 검사를 실시하는 기관도 1-2기관으로 새로 추가되었다(Table 7). 비예기항체 선별검사를 위해서 사용하는 적혈구는 1 차(2차)의 회신기관의 $1.3 \%(2.0 \%)$ 에서 자가제조법으로 제조하였고, 동정검사는 자가제조법으로 제조하는 기관은 없는 것으로 나타났다.

\section{6) 시범항목}

적혈구 $\mathrm{A}_{1}, \mathrm{H}$ 항원은 1 차 때만 실시하였는데 $\mathrm{A}_{1}$ 과 $\mathrm{O}$ 형의 2 개의 검체에 대하여 각각 $\mathrm{A}_{1}$ 항원검사 54 기관, $\mathrm{H}$ 항원검사 50 기관이 응답하여 $\mathrm{ABO}$ groping 참여기관인 542 기관의 각각 $9.7 \%$ 와 $9.2 \%$ 가 참여하였다. 정답은 전년도와 마찬가지로 $\mathrm{A}_{1}$ 형 검체의 경우 $\mathrm{A}_{1}$ 항원검사는 $2+$ 이상, $\mathrm{H}$ 항원검사는 $1+$ 이 하, $\mathrm{O}$ 형 검체의 경우 $\mathrm{A}_{1}$ 항원검사는 음성, $\mathrm{H}$ 항원검사는 $3+$ 이상으로 간주하였다. Anti- $\mathrm{A}_{1}$ 에 대한 반응은 $\mathrm{A}_{1}$ 형 검체에서

Table 5. Performance in direct antiglobulin test

\begin{tabular}{|c|c|c|c|c|}
\hline \multirow{2}{*}{ Survey no. } & \multirow{2}{*}{ Result (P, G, C) } & \multirow{2}{*}{ Polyspecific anti-human globulin } & \multicolumn{2}{|c|}{ Monospecific anti-human globulin } \\
\hline & & & Anti-IgG & Anti-C3d \\
\hline $2015-1$ & $(+,+,-)$ & $338 / 364(92.9)$ & $70 / 74(94.6)$ & $69 / 75(93.2)$ \\
\hline \multirow[t]{2}{*}{$2015-2$} & $(+,+,-)$ & $361 / 370(97.6)$ & $76 / 76(100.0)$ & $64 / 75(84.2)$ \\
\hline & $(-,-,-)$ & $355 / 368(96.5)$ & $73 / 73(100.0)$ & $73 / 74(98.6)$ \\
\hline
\end{tabular}

Values are presented as number of laboratories reporting correct results/total number of participating laboratories (\%). Abbreviations: P, polyspecific anti-human globulin; G, anti-IgG; C, anti-C3d; +, positive; -, negative.

Table 6. Performance in unexpected antibody screening and identification tests

\begin{tabular}{|c|c|c|c|c|c|c|}
\hline \multirow{2}{*}{ Survey no. } & \multicolumn{3}{|c|}{ Antibody screening test } & \multicolumn{3}{|c|}{ Antibody identification test } \\
\hline & Result & Participants & Correct answer (\%) & Result & Participants & Correct answer (\%) \\
\hline \multirow[t]{3}{*}{$2015-1$} & Positive & 299 & $295(98.7)$ & Anti-c & 132 & $131(99.2)$ \\
\hline & Positive & 299 & $298(99.7)$ & Anti-D & 132 & $132(100.0)$ \\
\hline & Positive & 148 & $140(94.5)$ & Anti-M & $131\left(1^{\star}\right)$ & $123(93.8)$ \\
\hline \multirow[t]{3}{*}{$2015-2$} & Positive & 300 & $299(99.7)$ & Ant-D & 132 & $132(100.0)$ \\
\hline & Negative & 300 & $300(100.0)$ & None & 132 & $132(100.0)$ \\
\hline & Positive & 148 & $147(99.3)$ & Anti-e & $132\left(3^{*}\right)$ & $129(97.7)$ \\
\hline
\end{tabular}

${ }^{\star} \mathrm{N}$ of non-responders. 


\section{Journal of LABORATORY MEDICINE and QUALITY ASSURANCE}

\section{Young Ae Lim et al • Annual Report on EQA in Blood Banks}

Table 7. Number (percentage) of participating laboratories reporting results for unexpected antibody screening and identification tests according to technique

\begin{tabular}{|c|c|c|c|c|}
\hline \multirow{2}{*}{ Technique } & \multicolumn{2}{|c|}{ Antibody screening } & \multicolumn{2}{|c|}{ Antibody identification } \\
\hline & 2015-1 (\%) & $2015-2(\%)$ & 2015-1 (\%) & $2015-2(\%)$ \\
\hline Column agglutination technology & $272(90.9)$ & $276(92.0)$ & $133(97.9)$ & $129(96.3)$ \\
\hline Tube & $22(7.4)$ & $20(6.7)$ & $1(0.7)$ & $3(2.3)$ \\
\hline Solid phase red cell adherence assay & $1(0.3)$ & $1(0.3)$ & $1(0.7)$ & $1(0.7)$ \\
\hline Erythrocyte-magnetized technique & $2(0.7)$ & $2(0.7)$ & $1(0.7)$ & $1(0.7)$ \\
\hline No results & $2(0.7)$ & $1(0.3)$ & 0 & 0 \\
\hline Total & $299(100.0)$ & $300(100.0)$ & $136(100.0)$ & $134(100.0)$ \\
\hline
\end{tabular}

Table 8. Results (\%) of testing for $\mathrm{A}_{1}$ and $\mathrm{H}$ antigens

\begin{tabular}{llclcc}
\hline \multirow{2}{*}{ ABO result } & \multicolumn{2}{c}{$\mathrm{A}_{1}(\mathrm{R} 1)$} & \multicolumn{2}{c}{$\mathrm{O}(\mathrm{R} 2)$} \\
\cline { 2 - 3 } \cline { 5 - 6 } & Anti- $\mathrm{A}_{1}$ & Anti-H & & Anti-A & Anti-H \\
\hline Negative & $1(1.8)$ & $14(28.0)$ & & $52(96.2)$ & 0 \\
Trace-1+ & 0 & $29(58.0)$ & $2(3.8)$ & $1(2.0)$ \\
$2+$ & $1(1.8)$ & $7(14.0)$ & & $2(4.0)$ \\
$3+$ & $1(1.8)$ & 0 & & $14(28.0)$ \\
$4+$ & $51(94.6)$ & 0 & & $33(66.0)$ \\
Total & $54(100.0)$ & $50(100.0)$ & $54(100.0)$ & $50(100.0)$ \\
\hline
\end{tabular}

Values are presented as participants (\%). R1 and R2 are the proficiency testing specimens for $\mathrm{ABO}$ and $\mathrm{RhD}$ typing.

$98.2 \%, \mathrm{O}$ 형 검체에서 $96.2 \%$ 를 보였으며, anti-H에 대한 반 응은 $\mathrm{A}_{1}$ 형 검체에서 $86.0 \%, \mathrm{O}$ 형 검체에서 $94.0 \%$ 로 나타났다 (Table 8).

Rh subgrouping 검사는 47개 기관에서 참여하였다. 정답은 $\mathrm{e}$ 항원과 $\mathrm{c}$ 항원에서 모두 $2+$ 이상으로 간주하였고, C 항원 과 $\mathrm{E}$ 항원은 음성을 정답으로 간주하였는데, 오답률은 $\mathrm{E}$ 항원 $4.3 \%$ 와 C와 e 항원에 응답을 하지 않아 $2.1 \%$ 씩을 나타냈다 (Table 9).

$\mathrm{ABO}$ 항체 역가검사는 2015년에는 2회차에만 1회 실시되 었는데, 각 방법별 참여기관의 수와 결과는 Table 10 과 같다. $\mathrm{ABO}$ 항체 IgM 측정을 위하여 2012년 표준안으로 제시된 시 험관 실온배양법에 비하여 시험관 즉시원침법을 사용하는 기 관이 더 많았고, $\operatorname{IgG}$ 측정을 위해서는 시험관 항글로불린법 15 기관, 미세원주응집법 항글로불린법 21기관이었다.

각 항체의 허용범위는 최빈도역가 \pm 1 배수로(혹은 최빈도역 가 \pm 1 배수의 값보다 빈도가 높은 경우에는 1 배수 이상의 값 포함) 정의하였고, 결과 입력기관이 10 기관 이상인 경우만 분 석하여 Table 10에 굵은 글씨로 표시하였다. 허용범위 산정에 대해서는 설명문을 홈페이지에 게시하였다. Anti-A (anti-B)
Table 9. Results (\%) of testing for C, c, E, and e antigens ( $\mathrm{n}=47)$

\begin{tabular}{lcccc}
\hline \multirow{2}{*}{ Result } & \multicolumn{4}{c}{ Rh subgrouping of R3 } \\
\cline { 2 - 5 } & $\mathrm{C}$ & $\mathrm{c}$ & $\mathrm{E}$ & $\mathrm{e}$ \\
\hline Negative & $45(95.8)$ & 0 & $43(91.4)$ & 0 \\
Trace-1+ & $1(2.1)$ & $1(2.1)$ & $2(4.3)$ & $1(2.1)$ \\
$2+$ & 0 & $5(10.6)$ & 0 & $6(12.8)$ \\
$3+$ & 0 & $9(19.2)$ & 0 & $13(27.7)$ \\
$4+$ & 0 & $31(66.0)$ & $2(4.3)$ & $26(55.3)$ \\
No results & $1(2.1)$ & $1(2.1)$ & 0 & $1(2.1)$ \\
\hline
\end{tabular}

$\mathrm{R} 3$ is the proficiency testing specimen for $\mathrm{ABO}$ and $\mathrm{RhD}$ typing.

의 최빈도 값의 배수는 시험관 즉시원침법 16 배(16배), 시험 관 실온배양법 32배(32배), 시험관 항글로불린법 16배와 64 배(32배), 미세원주응집법 항글로불린법 64배(32배와 64배) 순으로 나타났다. 허용범위에 드는 참여기관 비율은 anti-A 와 anti-B의 경우 각각 시험관 즉시 원침법은 모두 $85.3 \%$ (29/34), 시험관 실온배양법도 모두 94.1\% (16/17), 시험관 항글로불린법 86.7\% (13/15)와 80.0\% (12/15), 미세원주응 집 항글로불린법 95.2\% (20/21)로 가장 일치율이 높았다.

\section{3. 워크숍 개최}

2014까지 매년 2회 실시하던 혈액은행 실기 및 이론 워크솝 을 메르스 감염여파로 인하여 2015년 8월 28일(금) 오전 9시 부터 17 시까지 아주대학교 의과대학 송재관학생실습실에서 1 회만 개최하였다. 내용은 $\mathrm{ABO}$ 아형, $\mathrm{RhD}$ 변이형 검체검사 검출법, 비예기항체 검출원리, 비예기항체 선별과 동정에 대 하여 실시하였다. 오전에는 이론 강의를 실시하였는데 57 명이 참석하였고, 오후에는 실습이 이루어졌으며 49명이 참석하였 다. 
Journal of LABORATORY MEDICINE and QUALITY ASSURANCE

Young Ae Lim et al • Annual Report on EQA in Blood Banks

Table 10. Number of participating laboratories reporting ABO antibody titration results according to the technique

\begin{tabular}{|c|c|c|c|c|c|c|c|c|c|c|c|c|c|}
\hline Techniques & $\mathrm{N}$ & Negative & $1: 1$ & $1: 2$ & $1: 4$ & $1: 8$ & $1: 16$ & $1: 32$ & $1: 64$ & $1: 128$ & $1: 256$ & $1: 512$ & $\leq 1: 1,024$ \\
\hline \multicolumn{14}{|l|}{ Anti-A } \\
\hline Tube-IS $(85.3 \%)^{*}$ & 34 & 0 & 0 & 0 & 1 & 7 & 12 & 10 & 4 & 0 & 0 & 0 & 0 \\
\hline Tube-AHG $(86.7 \%)^{\star}$ & 15 & 0 & 0 & 0 & 0 & 0 & 6 & 2 & 5 & 2 & 0 & 0 & 0 \\
\hline CAT-RT & 7 & 0 & 0 & 0 & 0 & 0 & 3 & 2 & 2 & 0 & 0 & 0 & 0 \\
\hline DTT treatment & 10 & 0 & 0 & 0 & 1 & 1 & 0 & 4 & 1 & 3 & 0 & 0 & 0 \\
\hline Other & 0 & 0 & 0 & 0 & 0 & 0 & 0 & 0 & 0 & 0 & 0 & 0 & 0 \\
\hline \multicolumn{14}{|l|}{ Anti-B } \\
\hline Tube-IS $(85.3 \%)^{*}$ & 34 & 1 & 0 & 0 & 4 & 7 & 13 & 9 & 0 & 0 & 0 & 0 & 0 \\
\hline CAT-AHG $(95.2 \%)^{*}$ & 21 & 0 & 0 & 0 & 0 & 0 & 2 & 8 & 8 & 2 & 1 & 0 & 0 \\
\hline DTT treatment & 10 & 0 & 0 & 0 & 0 & 2 & 1 & 1 & 4 & 2 & 0 & 0 & 0 \\
\hline Other & 0 & 0 & 0 & 0 & 0 & 0 & 0 & 0 & 0 & 0 & 0 & 0 & 0 \\
\hline
\end{tabular}

Bold characters express the allowable range for ABO Ab titers.

Abbreviations: IS, immediate spin; RT, room temperature incubation; AHG, indirect anti-human globulin test; CAT, column agglutination technology; DTT, dithiothreitol.

${ }^{\star}$ Percentage of participating laboratories with results within the allowable range.

고찰

2015년 혈액은행분과 신빙도조사의 참여 회신율은 2014년 도 541기관에서 543기관으로 증가하였고, 회신율 또한 2013 년 97.3\%, 2014년 98.1\% 2015년 98.4\%로 소폭 상승하였다 $\lceil 1,2]$. 2015년도에는 정도관리 사업비를 지불하여 참여의사를 확실히 보인 기관에게만 검체를 발송하였으나 회신율이 예상 만큼 증가하지는 않은 것으로 보인다.

$\mathrm{ABO}$ 와 $\mathrm{D}$ 혈액형 정답률은 전년도와 유사하였고, 작년에 비하여 미입력 기관이 감소하였기는 하나 여전히 발생하고 있 었다. 미입력은 검사가 까다롭다고 여겨지는 경우 참여기관들 이 고의로 입력하지 않거나 혹은 사무적 착오일 수 있는데, 혈 액형검사의 경우 검사가 까다로운 편은 아니라 대부분 사무적 착오로 여겨졌다. 자동화장비로 결과가 자동전송되는 검사들 과는 달리 혈액형검사의 경우 국내 대부분의 검사실이 수기법 으로 시행하여 결과를 입력하여야 하므로 사무적 착오를 점검 하는 것은 매우 중요하다고 할 수 있다.

ABO와 D 혈액형검사법은 2014-2차 때 슬라이드법을 지양 하는 교육문 발송 후 검사법의 변화를 보였다. 즉 $\mathrm{ABO}$ 혈액 형의 경우 슬라이드법과 시험관법의 사용이 2014-1차 61.6\%
와 $36.8 \%, 2014-2$ 차 $49.5 \%$ 와 $49.3 \%, 2015-1$ 차 $40.2 \%$ 와 $49.3 \%, 2015-2$ 차 $42.1 \%$ 와 $50.2 \%$ 로 2015년에 들어 시험관 법이 슬라이드법을 앞질렀으며, $\mathrm{RhD}$ 혈액형도 유사한 양상을 보였다. 이는 교육문 및 검사법에 대한 다양한 교육에 대한 효 과로 여겨지며, 향후에도 이러한 교육을 더 장려할 필요가 있 을 것으로 여겨졌다.

교차시험의 오답은 부적합 검체를 적합한 것으로 잘못 판 정한 경우가 1차(2차) $93.6 \%$ (94.6\%)로 2014년도 91.4\% (91.2\%)에 비하여 소폭 증가하였다. 그러나 부적합 검체의 경 우 각 단계별에서 실온식염수 단계와 알부민 단계에서 거의 검 출되지 않는 부적합 검체의 응집을 강하게 판독한 기관들이 1 차 $12.8 \%, 2$ 차 $7.3 \%$ 를 보였는데, 이 기관들이 비록 교차시험 의 최종 판정을 정답을 보고하였다 하더라도 각 단계별 응집 강도 정도를 감안할 경우, 이러한 검사실들의 경우 교차시험의 검사과정을 점검할 필요가 있을 것으로 생각된다(Table 4).

비예기항체 선별 및 동정검사에 사용된 anti-M는 $93.8 \%$ 로 2015년 발송된 검체 중 가장 낮은 정답률을 보였다. 이 검체는 상품화된 항혈청이 아니라 헌혈자로부터 채집된 혈장이라 실 제 환자 혹은 헌혈자 검체의 특성을 그대로 반영할 수 있었다 는 장점이 있었다. Anti-M은 한랭항체인 경우도 있으나 이 검 


\section{Journal of LABORATORY MEDICINE and QUALITY ASSURANCE}

Young Ae Lim et al • Annual Report on EQA in Blood Banks

체의 경우 $37^{\circ} \mathrm{C}$ 에서도 반응하므로 수혈 전 반드시 검출할 수 있어야 하는 항체이다. Anti-M은 신빙도조사의 검체로 자주 이용되는 항체가 아닌 이유로 정답률이 다른 검체에 비하여 낮 은 것으로 분석되었다. 따라서 가능한 인간에서 유래된 혈장 중 신빙도조사의 검체로 자주 이용되는 항체는 아니나 임상적 으로 의미가 있는 항체를 신빙도조사용 검체로 사용하는 것이 바람직할 것으로 여겨졌다.

$\mathrm{A}_{1}$ 형과 $\mathrm{H}$ 항원검사 참여기관은 50-54개로 2014년도 53-48 기관과 유사하였다. Anti- $\mathrm{A}_{1}$ 에 대한 반응은 비록 2014년도 $100 \%$ 에 비하여 약간 감소하였기는 하나 anti-H의 정답률에 비해서는 여전히 높았다. Anti-H는 O형 검체의 경우 2+ 이 하로 보고하는 기관이 $6.0 \%, \mathrm{~A}_{1}$ 형 검체의 경우 $2+$ 이상을 보 고하는 기관이 $14.0 \%$ 나 되므로 특히 anti-H 시약의 검사법에 대하여 주의를 기울여야 할 필요가 있는 것으로 판단되었다. 시범항목인 적혈구 $\mathrm{A}_{1}, \mathrm{H}$ 항원검사에 사용되는 시약은 3 등급 체외진단제품으로 2012년 12월까지 식약처 허가를 득하여야 국내에 시약 공급이 가능하나, 2014년도 보고서에 지적하였듯 이 아직도 $\mathrm{H}$ 항원검사 시약에 대한 식약처 허가를 득한 국내 업체가 없는 실정이다. 환자들의 안전을 위하여 이러한 희귀 시약들의 허가제도 개선에 대한 협회나 유관학회의 적극적인 홍보와 요구가 필요할 것으로 여겨졌다.

47개 기관이 참여한 Rh subgrouping 결과의 정답률은 우수 하였으나, $\mathrm{E}$ 항원이 음성인 검체를 $4+$ 로 답변한 기관이 2 기 관이 있어 해당기관에서는 이것이 사무적 착오인지 기술적 오 류인지를 감별하여 검사과정을 검토할 필요가 있을 것으로 여 겨졌다.

검사실들은 각기 검사실에 맞추어 여러 가지 $\mathrm{ABO}$ 항체 역 가 측정방법들을 사용하고 있는데, 항체 민감도는 미세원주응 집법 항글로불린법, 시험관 항글로불린법, 시험관 실온배양법, 시험관 즉시원침법 순이었으며, 일치율도 미세원주응집법 항 글로불린법이 가장 높았으며 그 뒤로 시험관 실온배양법이었
으며, 시험관 즉시 원침법과 시험관 항글로불린법은 일치율이 높지 않아 미세원주응집법 항글로불린법이 가장 우수한 것으 로 나타났다.

2015년에 실시한 6가지 정식 신빙도조사 항목뿐 아니라 3 가 지 종류의 시범항목에도 꾸준히 참여한 기관 수도 적지 않았으 므로 혈액은행분과의 신빙도조사는 국내 혈액은행 검사실의 수준 향상에 도움을 주는 것으로 평가할 수 있었다.

\section{REFERENCES}

1. Lim YA, Oh JS, Kwon SW, Kwon KC, Kim SY, Park KU, et al. Annual report on the external quality assessment scheme for blood bank tests in Korea (2014). J Lab Med Qual Assur 2015;37:47-55.

2. Lim YA, Oh JS, Kwon SW, Kwon KC, Kim SY, Park KU, et al. Annual report on external quality assessment of blood bank tests in Korea (2013). J Lab Med Qual Assur 2014;36:55-63.

3. Lim YA, Oh JS, Kwon SW, Kwon KC, Kim SY, Park KU, et al. Annual report on external quality assessment in blood bank tests in Korea (2012). J Lab Med Qual Assur 2013;34(S1):S103-S15.

4. Lim YA, Oh JS, Kwon SW, Kwon KC, Kim SY, Park KU, et al. Annual report on external quality assessment in blood bank tests in Korea (2011). J Lab Med Qual Assur 2012;33(S1):S91-S104.

5. Lim YA, Oh JS, Kwon SW, Kwon KC, Kim SY, Park KU, et al. Annual report on external quality assessment in blood bank tests in Korea (2010). J Lab Med Qual Assur 2011;33(S1):S75-S89. 
혈액은행분과 신빙도조사 결과보고(2015)

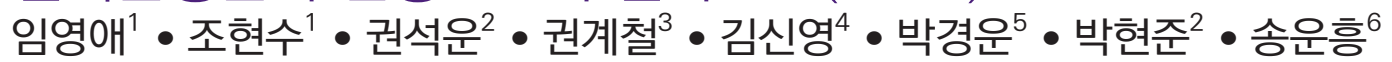
조 덕 $\bullet$ 엄태현 ${ }^{8}$ 이미경 한상무 $^{10}$ - 대한임상검사정도관리협회 혈액은행 분과위원회

${ }^{1}$ 아주대학교 의과대학 진단검사의학과, ${ }^{2}$ 울산대학교 의과대학 서울아산병원 진단검사의학과, ${ }^{3}{ }^{3}$ 창남대학교 병원 진단검사의학과, ${ }^{4}$ 연세대학교 의과대학 세브란스병원 진단검사의학과, ${ }^{5}$ 분당서울대학교병원 진단검 사의학과, ${ }^{6}$ 신한대학교 보건과학대학 임상병리학과, ${ }^{7}$ 화순전남대학교병원 진단검사의학과, ${ }^{8}$ 인제대학교 일 산백병원 진단검사의학과, ${ }^{9}$ 대한적십자사 중앙혈액검사센터, ${ }^{10}$ 대한적십자사 경기혈액원

2015년에 시행된 혈액은행검사에 대한 신빙도조사 결과를 분석하였다. 검체는 아주대학교병원에 서 직접 제조하였으며, 검체 발송기관 수는 1차 549기관과 2차 554기관이다. 평가종목은 $\mathrm{ABO}$ 혈 액형검사, $\mathrm{RhD}$ 혈액형검사, 교차시험검사, 직접항글로불린검사, 비예기항체 선별검사 및 동정검사 였다. 검체 발송기관에 대한 1차와 2차의 회신율은 각각 98.7\% (542/549)와 98.2\% (544/554)였 다. 미입력은 오답으로 처리하였고, 평가종목에 대한 평균 정답률은 다음과 같았다. $\mathrm{ABO}$ 혈액형검사 99.4\%-100.0\%; RhD 혈액형검사 99.4\%-100.0\%; 교차시험검사 93.6\%-99.0\%; 다특이성 직 접항글로불린검사 92.9\%-98.3\%; IgG 단특이성 직접항글로불린검사 $94.6 \%-100.0 \%$; C3d 단특 이성 직접항글로불린검사 84.2\%-98.6\%; 항체 선별검사 94.5\%-100.0\%; 그리고 항체 동정검사 93.8\%-100.0\%이었다. 시범항목(참여기관 수)은 $\mathrm{A}_{1}$ (54), H (50), Rh C, c, E, 그리고 e 항원에(47) 대한 반응과 $\mathrm{ABO}$ 항체 역가(10-34)였다. 2015년도 혈액은행분과의 신빙도조사 결과는 전반적으로 우수한 편이었으며 참여기관들의 질 향상과 유지에 도움을 준 것으로 보여졌다.

(J Lab Med Qual Assur 2016;38:59-67)

교신저자: 임영애

우)16499 경기도 수원시 영통구 월드컵로 164 , 아주대학교 의과대학 아주대학교병원 진단검사의학과

Tel: 031)219-5786, Fax: 031)219-5778, E-mail: limyoung@ajou.ac.kr 